JOURNAL

of Health Inequalities

\title{
Give it up! - a new mobile app and campaign supporting women to quit smoking in Poland - project rationale and app description
}

\author{
Małgorzata Stelmach', Kinga Janik-Koncewicz ${ }^{2,3}$, Aleksandra Herbeć ${ }^{2}$, Katarzyna Wijatkowska², \\ Andrzej Wojtyła ${ }^{4}$, Witold A. Zatoński ${ }^{2,4,5}$ \\ 'MSD Foundation for Women's Health, Warsaw, Poland \\ ${ }^{2}$ Health Promotion Foundation, Nadarzyn, Poland \\ ${ }^{3}$ PhD Candidate, University of Aberdeen, UK \\ ${ }^{4}$ European Observatory of Health Inequalities, State University of Applied Sciences, Kalisz, Poland \\ ${ }^{5}$ Wroclaw Medical University, Poland
}

\begin{abstract}
Smoking during pregnancy is one of the most dangerous health behaviours. Historically, smoking during pregnancy in European countries was common. At the end of $20^{\text {th }}$ century in many European countries, including Poland, around $20-40 \%$ of children were born after 9 month exposure to toxic factors of tobacco smoke. In the last decades prevalence of smoking among women has declined substantially. In 2015, the overall smoking prevalence among women in the WHO European region was 19.1\%, while among pregnant women it was $5.9 \%$. Female smoking rates in Asia contrast sharply with Europe. In the WHO Western Pacific region only $1.1 \%$ of women, and only $0.9 \%$ of pregnant women, are smokers. In 2017 in Poland around 23 thousand children were born to mothers smoking during pregnancy. Therefore, the Health Promotion Foundation, in collaboration with MSD Foundation for Women's Health, undertook the initiative to help Polish women quit smoking using new technologies. A mobile app called "Give it up!" has been created. This Polish-language app is designed for young women, especially those who are expecting a baby or thinking about motherhood. This publication presents the programme rationale and app description.
\end{abstract}

KEY WORDS: pregnancy, digital intervention, smoking cessation, smartphone app.

ADDRESS FOR CORRESPONDENCE: Małgorzata Stelmach, MSD Foundation for Women's Health, 51 Chłodna Street, 00-867 Warsaw, Poland, phone: +48601947746, e-mail: biuro@fzk.org.pl

\section{INTRODUCTION}

Smoking is one of the most dangerous health behaviours, and tobacco kills up to $50 \%$ of its users [1]. Smoking during pregnancy carries additional risks. Importantly, in most countries there is limited availability of evidence-based cessation support, and this includes services dedicated to women who are pregnant and smoking. Digital behaviour change intervention (DBCI) such as websites or smartphone apps could provide behavioural support to pregnant smokers wanting to quit, especially if they cannot or do not want to access traditional face-to-face support, although research on the topic remains limited [2-5]. To date, no smartphone-based intervention supporting quitting smoking has been developed to support women in Poland to quit. Give it up! is a new campaign accompanied by a smartphone app that is aimed to assist quit attempts among Polish women using smartphones. 


\section{HEALTH RISKS OF MATERNAL SMOKING}

Epidemiological studies have shown that maternal smoking (active and passive) is associated with a number of adverse effects during pregnancy [6,7]. Smoking increases the risk of miscarriage, stillbirth, prematurity, low birthweight, perinatal morbidity and mortality, neonatal or sudden infant death, asthma, attention deficit hyperactivity disorder, learning difficulties, obesity, and diabetes [8] as well as birth deformities [9]. Furthermore, being exposed to second hand smoke is related to cot death, asthma and ear infections among children [10].

There is no harmless dose of smoke to which the growing foetus may be exposed and thus it is recommended that women who smoke during pregnancy should be advised by health providers to quit smoking completely. Furthermore, to minimalize harmful effects on a child, women should be encouraged to stop smoking before planning the pregnancy and to refrain from smoking postpartum.

\section{EPIDEMIOLOGY OF SMOKING DURING PREGNANCY}

Smoking during pregnancy, although gradually declining over the past decades, remains above $10 \%$ in many Western countries of the WHO European region, including Ireland, Spain and Denmark [11]. However, in some countries, including Iceland, Slovenia, Slovakia, Romania and most Newly Independent States (i.e. Georgia, Kazakhstan, Armenia, Moldova, Turkmenistan, Azerbaijan, Kyrgyzstan, Uzbekistan, Tajikistan), cigarette use among pregnant women is below 5\% [11]. In 2015, the overall smoking prevalence among women in the WHO European region was $19.1 \%$, while among pregnant women it was $5.9 \%$. Female smoking rates in Asia contrast sharply with Europe. In the WHO Western Pacific region only $1.1 \%$ of women, and only $0.9 \%$ of pregnant women, are smokers [11]. In Chinese literature it's suggested that one of the most important reasons behind this low prevalence is the fear of the health effects smoking might have on the foetus [12]. This might also help explain the smoking differences between sexes. In China less than $2 \%$ of all women smoked in 2016 [13], but the prevalence of smoking among Chinese men was 52.9\% [13, 14].

In Poland smoking prevalence among women grew rapidly after the Second World War. In the years 1960 1980 , the prevalence of female smokers doubled, and by the early 1990s almost $50 \%$ of Polish women aged 20-44 smoked [15]. At the same time, the frequency of smoking during pregnancy was about $30 \%$, and in some groups, for example, among working women in Łódź, it was as high as $50 \%$ [16]. The reduction of smoking during pregnancy became an important part of the public health debate, and featured prominently in the anti-tobacco campaigns of the 1990s, the 1995 Polish Anti-tobacco Law [17], and in the National Tobacco Control Programme, launched in 1995.
After 25 years of implementing these, and other strong anti-tobacco measures, the smoking prevalence among pregnant women significantly decreased [18]. In recent years, several studies measuring smoking among women have been conducted. In the years 2005-2007 $11.6 \%$ of pregnant women smoked [19], in 2010-2012 in the last trimester of pregnancy smoking prevalence among women was $7.7 \%$, in $2013-6.99 \%$ [20], and in $2017-5.86 \%$ [18]. It also seems that conditions are conducive for a further decline in smoking among pregnant women. Research conducted by Wojtyła et al. indicates that the knowledge of women in Poland about smoking in pregnancy and its risk is very high, and compares favourably to knowledge about the adverse effects of drinking alcohol during pregnancy [6].

\section{MOBILE AND INTERNET OPPORTUNITIES FOR EFFECTIVE INTERVENTIONS}

In 2018, among Poland's 38 million inhabitants, around 30 million used the Internet (78\% of the population). Almost half of them actively use social media, and 11 million (37\% of all internet users) are using smartphones to communicate with other users via the Internet. Number of mobile phone users continues to increase considerably in Poland, as well globally [21].

Over 260,000 health mobile apps are available on the global market [22]. These apps have an important role in facilitating access to health: they can provide expert knowledge, facilitate contact with specialists, help locate a health provider, or be used as tools for health promotion programmes. The potential of social media is particularly strong. For example, Facebook is used by over $80 \%$ of young people in the USA, while platforms such as Instagram or Snapchat have seen very dynamic increases in the number of users in the last years, and are expected to grow further in the coming years [23]. In Poland apps for health monitoring, physical activity, or diet, are used by $5 \%$ of smartphone users. Social media and mobile apps can be a useful tool allowing to effectively disseminate health competencies to a wide audience. Similarly to internet-based interventions, mobile apps are also suitable for smoking cessation during pregnancy; they are flexible, remote and non-judgmental [4]. However, although such intervention are seem attractive and offer wide reach, at least in theory, there exists only very limited research about their effectiveness for real behaviour $[3,4,24]$.

\section{NEW SMOKING CESSATION APPLICATION DEDICATED TO WOMEN}

In 2018, the Health Promotion Foundation, in cooperation with the MSD Foundation for Women's Health, has launched a new campaign to help Polish women quit smoking. As part of this effort, a mobile app called Give it up! has been created. This Polish-language app is designed for young women, especially those who 
are expecting a baby or thinking about motherhood. The app is also intended to help people who are around pregnant women - for example their friends, partners, and family - and, who are struggling with tobacco addiction. The app has been created by specialists with many years of experience with smoking cessation, and contains evidence-based information, advice, and tips on methods of dealing with tobacco dependence.

The goal of the Give it up! campaign, as well as the accompanying app (available for free for Android and iOS), is to prepare its users to make a serious quit attempt. The support offered within the app will include (1) informational and educational content about the health risks associated with smoking, evidence-based support available, including pharmacotherapy, (2) motivating content to initiate a quit attempt, as well as (3) behaviour change techniques shown to be effective at improving quit rates, such as goal setting and monitoring. Planned or current pregnancy will be discussed as important motivation for quitting, but other reasons will also be discussed.

Women using the app for the first time start by defining their degree of addiction to tobacco and determining the motivation. The app then monitors their progress in smoking cessation, and indicates how to deal with difficulties that can accompany this process. The app consists of several sections that have informational and guidance functions. The section "About smoking" explains in an accessible way the mechanism of nicotine addiction, and presents specific negative effects of smoking. In the "How to quit smoking" section users find concrete advice on how undergo a quit attempt. The users will be able to choose the quit date (i.e. the first day without a cigarette), and monitor their progress. The application provides practical information describing the typical situations and motives that lead to picking up a cigarette again (e.g. stress, lack of supportiveness in the smokers' environment), and suggests tips for dealing with each of them. The section "Coping without a cigarette" offers tips on how to stay smoke-free and how to deal with nicotine withdrawal and cravings. The "Smokers around me" section contains information on passive smoking and advice on how to help someone who is trying to quit smoking.

\section{THE GIVE IT UP! CAMPAIGN}

The Give it up! campaign and app are primarily addressed to young women. The Polish name of the initiative, Rzuć go! is a playful pun reminiscent of the expression signifying breaking up with a boyfriend, and was consulted with young women through informal consultations. The creators of the campaign hope that the provocative name can help attract audience attention and stimulate a debate on the topic of tobacco addiction. Social media activities on Facebook and Instagram will be used to promote the application. Simultaneously, interviews with health experts and stories of women who successfully quit smoking will be published in the media targeting young girls and women, as well as websites and parenting publications.

\section{CONCLUSIONS}

Smoking during pregnancy is one of the most important preventable causes of negative maternal and foetal health outcomes. Smoking prevalence among young women is the determinant of smoking prevalence in pregnancy. It seems that evidence-based knowledge on primary prevention and smoking cessation combined with up-to-date modern technologies used in practice among young people could be one of the best models leading to reduce tobacco smoking in pregnant women.

The number of smoking pregnant women in Poland in 2017 was 23.5 thousand. Taking into consideration the broad network of gynaecological-obstetric settings in Poland, it seems that each of these women could be covered by a special educational programme (available on request). Programme entitled "Zero tolerance for annual exposure of 23 thousand foetuses on tobacco smoke" should be one of the public health priorities in Poland. Give it up! programme would be one of the tools to support such initiative.

\section{DISCLOSURE}

The project was funded by MSD Foundation for women's health. AH and WZ have received unrestricted funds as part of a project Global Bridges at Mayo Clinic and Pfizer Independent Grants for Learning and Change Request for Proposals (RFP): EUROPEAN PROGRAM to develop STAR programme in Poland.

\section{References}

1. Peto R, Lopez AD, Pan H, Boreham J, Thun M. Mortality from smoking in developed countries 1950-2020 (updated September 2015) Available from: http://gas.ctsu.ox.ac.uk/tobacco/ index.htm (accessed: 05 February 2018).

2. Herbec A, Brown J, Tombor I, Michie S, West R. Pilot randomized controlled trial of an internet-based smoking cessation intervention for pregnant smokers ('MumsQuit'). Drug Alcohol Depend 2014; 140: 130-136.

3. Tombor I, Beard E, Brown J, Shahab L, Michie S, West R. Randomised factorial experiment of components of the SmokeFree Baby smartphone application to aid smoking cessation in pregnancy. Transl Behav Med 2018; doi: 10.1093/tbm/iby073 [Epub ahead of print].

4. Griffiths SE, Parsons J, Fulton EA, Naughton F, Tombor I, Brown KE. Are digital interventions for smoking cessation in pregnancy effective? A systematic review and meta-analysis. Health Psychol Rev 2018; doi: 10.1080/17437199.2018.1488602 [Epub ahead of print].

5. Herbec A, Beard E, Brown J, Gardner B, Tombor I, West R. The needs and preferences of pregnant smokers regarding tailored Internet-based smoking cessation interventions: a qualitative interview study. BMC public health 2014; 14: 1070. 
6. Wojtyła C, Wojtyła-Buciora P. Cigarette smoking among pregnant women in Poland. J Health Inequal 2017; 3: 47-50.

7. Banderali G, Martelli A, Landi M, Moretti F, Betti F, Radaelli G, Verduci E. Short and long term health effects of parental tobacco smoking during pregnancy and lactation: a descriptive review. J Transl Med 2015; 13: 327.

8. Cnattingius $\mathrm{S}$. The epidemiology of smoking during pregnancy: smoking prevalence, maternal characteristics, and pregnancy outcomes. Nicotine Tob Res 2004; Suppl 2: S125-S140.

9. Hackshaw A, Rodeck C, Boniface S. Maternal smoking in pregnancy and birth defects: a systematic review based on 173687 malformed cases and 11.7 million controls. Hum Rep Update 2011; 17: 589-604.

10. Hawkins SS, Hristakeva S, Gottlieb M, Baum CF. Reduction in emergency department visits for children's asthma, ear infections, and respiratory infections after the introduction of state smoke-free legislation. Prev Med 2016; 89: 278-285.

11. Lange S, Probst C, Rehm J, Popova S. National, regional, and global prevalence of smoking during pregnancy in the general population: a systematic review and meta-analysis. Lancet Glob Health 2018; 6: e769-e776.

12. Yin H, Chen X, Zheng P, Kegler M, Shen Q, Xu B. A neglected opportunity for China's tobacco control? Shift in smoking behaviour during and after wives' pregnancy. Tob Induc Dis 2016; $14: 39-45$

13. World Health Organization. Global Health Observatory Data Repository. Available from: https://data.worldbank.org/indicator/ SH.PRV.SMOK.FE?locations=CN (accessed: 5 February 2018).

14. Global Adult Tobacco Survey (GATS) China 2010 Country Report. Available from: http://www.who.int/tobacco/surveillance/ survey/gats/en_gats_china_report.pdf?ua=1 (accessed: 5 February 2018).

15. Zatoński WA, Zatoński M, Janik-Koncewicz K, Połtyn-Zaradna K, Wijatkowska K, Marciniak A. Hundred years of cigarette smoking in Poland: three phases of the tobacco epidemic. J Health Inequal 2017; 3: 118-122.

16. Zatoński W, Przewoźniak K (red). Palenie tytoniu w Polsce: postawy, następstwa zdrowotne i profilaktyka [Tobacco smoking in Poland: attitudes, health consequences and prevention]. Wyd. II. Centrum Onkologii - Instytut im. M. Skłodowskiej-Curie, Warszawa 1999.

17. Dz. U. 1996 nr 10, poz. 55 [Journal of Laws of the Republic of Poland, 1996, no. 10, pos. 55].

18. Państwowa Inspekcja Sanitarna. Raport z badania - zachowania zdrowotne kobiet w ciąży [The Chief Sanitary Inspection research report - health behaviours of pregnant women]. ProVision Solutions, Warszawa 2017.

19. Wierzejska R, Jarosz M, Sawicki W, Stelmachow J, Siuba M. Antyzdrowotne zachowania kobiet ciężarnych. Tytoń, alkohol, kofeina [Anti-health behaviours of pregnant women. Tobacco, alcohol, caffeine]. Żyw Człow 2011; 38: 84-98.

20. Raport „Zachowania zdrowotne kobiet w ciąży” [Report: Health behaviours of pregnant women]. Instytut Medycyny Wsi im. Witolda Chodźki, Lublin 2013.

21. Główny Urząd Statystyczny. Statystyka międzynarodowa. Abonenci telefonii komórkowej [Main Sttistical Office. Inter- national statistics. Mobile telephone subscribers]. Available from: http://stat.gov.pl/statystyka-miedzynarodowa/porownania-miedzynarodowe/tablice-o-krajach-wedlug-tematow/ transport-i-lacznosc/ (accessed: 05 February 2018).

22. Research 2 Guidance. mHealth App Developer Economics 2016. The current status and trends of the mHealth app market. Available from: https://research2guidance.com/r2g/ r2g-mHealth-App-Developer-Economics-2016.pdf (accessed: 05 February 2018).

23. US Teens and Their Smartphones: The All-Purpose Device for Liking, Snapping, Ad Avoiding, Shopping and More. Report eMarketer. Available from: https://www.emarketer. com/Report/US-Teens-Their-Smartphones-All-Purpose-Device-Liking-Snapping-Ad-Avoiding-Shopping-More/2002116 (accessed: 05 February 2018).

24. Haskins BL, Lesperance D, Gibbons P, Boudreaux ED. A systematic review of smartphone applications for smoking cessation. Transl Behav Med 2017; 7: 292-299.

\section{AUTHOR'S CONTRIBUTIONS}

MS, KJK and KW prepared the first version of the manuscript. All authors contributed to preparing the final version of the publication. 